\title{
Mechanical stress in the inner bark of 15 tropical tree species and the relationship with anatomical structure ${ }^{1}$
}

\author{
Romain Lehnebach, Léopold Doumerc, Bruno Clair, and Tancrède Alméras
}

\begin{abstract}
Recent studies have shown that the inner bark is implicated in the postural control of inclined tree stems through the interaction between wood radial growth and tangential expansion of a trellis fiber network in bark. Assessing the taxonomic extent of this mechanism requires a screening of the diversity in bark anatomy and mechanical stress. The mechanical state of bark was measured in 15 tropical tree species from various botanical families on vertical mature trees, and related to the anatomical structure of the bark. Significant tensile or compressive longitudinal stresses were observed in the stems of most species. Tensile longitudinal stress was observed in various botanical families and was always associated with fibers arranged in a trellis-like structure and strong dilatation of rays. The highest tensile stress was recorded in species with gelatinous fibers forming a treillis. Compressive stress was typically associated with a large amount of sclereids in the bark, supporting the differen-tiation of sclereids as a potential origin of the generation of longitudinal compressive stresses in bark. In species exhibiting both a fibrous trellis structure and a significant amount of sclereids, the sign of longitudinal stress may depend on the balance between these two mechanisms.
\end{abstract}

Key words: bark anatomical structure, mechanical stress, sclereids, secondary phloem, tree biomechanics, tropical species.

Résumé : De récentes études ont mis en évidence que l'écorce interne est impliquée dans le maintien de la posture des tiges inclinées grâce à l'interaction entre la croissance radiale du bois et l'extension tangentielle d'un réseau de fibres en treillis dans l'écorce. L'évaluation de l'étendue taxonomique de ce mécanisme requiert une analyse plus importante de la diversité des structures anatomiques et des états de contrainte de l'écorce. L'état mécanique de l'écorce a été mesuré chez 15 espèces tropicales de diverses familles botaniques sur des arbres adultes verticaux, et mis en relation avec sa structure anatomique. Des contraintes longitudinales significatives ont été mises en évidence chez la plupart des espèces. Selon l'espèce, ces contraintes consistaient soit en une tension soit en une compression. La contrainte de tension longitudinale, observée ici sur diverses familles botaniques, était toujours associée à des fibres arrangées en treillis et une forte dilatation des rayons. La tension la plus forte a été mesurée chez les espèces cumulant la structure de fibres en treillis et la présence de couches gélatineuses. La contrainte de compression est typiquement associée à une grande quantité de sclérites, suggérant que la différenciation de sclérites est potentiellement impliquée dans la genèse de contraintes longitudinales de compression dans l'écorce. Chez les espèces, présentant à la fois une structure de fibres en treillis et une quantité significative de sclérites, le signe de la contrainte longitudinale pourrait dépendre de la balance entre ces deux mécanismes.[Traduit par la Rédaction]

Mots-clés : anatomie de l'écorce, biomécanique de l’arbre, contraintes mécaniques, espèces tropicales, sclérites, phloème secondaire.

R. Lehnebach.* Laboratoire de Mécanique et Génie Civil (LMGC), Université de Montpellier, CNRS, 860 rue de St. Priest, 34090 Montpellier, France; UGCT-UGent-Woodlab, Laboratory of Wood Technology, Department of Environment, Gent University, Coupure Links 653, B-9000 Gent, Belgium.

L. Doumerc. CNRS, UMR Ecologie des Forêts de Guyane (EcoFoG), AgroParisTech, CIRAD, INRA, Université des Antilles, Université de Guyane, Campus agronomique, BP 316, F-97379 Kourou cedex, France.

B. Clair. CNRS, UMR Ecologie des Forêts de Guyane (EcoFoG), AgroParisTech, CIRAD, INRA, Université des Antilles, Université de Guyane, Campus agronomique, BP 316, F-97379 Kourou cedex, France; Laboratoire de Mécanique et Génie Civil (LMGC), Université de Montpellier, CNRS, 860 rue de St. Priest, 34090 Montpellier, France.

T. Alméras. Laboratoire de Mécanique et Génie Civil (LMGC), Université de Montpellier, CNRS, 860 rue de St. Priest, 34090 Montpellier, France.

Corresponding author: Romain Lehnebach (email: lehnebach.romain@hotmail.fr). 


\section{Introduction}

To maintain the vertical posture during growth, selfsupporting woody plants developed mechanisms to generate the mechanical forces that offset the effect of gravity (Alméras and Fournier 2009). The understanding of such mechanisms was mainly achieved through the study of the inward cambial production, i.e., the wood or secondary xylem. During the process of wood formation in angiosperms, the maturation of cell walls generates tensile forces at the periphery of the wood cylinder in vertical stems (Clair et al. 2013). When the stem is inclined, the secondary cell wall typically shifts into a peculiar gelatinous layer (G-layer) producing higher tensile stress than normal fibers (Fang et al. 2008). This motor function in trees has long been considered to be achieved exclusively by the wood (Scurfield 1973; Fournier et al. 2014). Recent advances in plant biomechanics however have shown that the inner bark is also implicated in the control of the woody plant posture through the generation of mechanical stress (Clair et al. 2019).

The inner bark or secondary phloem is the product of outward cambial activity involved in many plant functions such as translocation of carbohydrates, storage, protection against herbivores and fire, and mechanical support (Niklas 1999; Evert 2006; Rosell et al. 2014, 2015). The multifunctionality of the inner bark results in a strong structural heterogeneity afforded by a large diversity of cells types: sieve tubes, fibers, axial and ray parenchyma, and sclereids (Angyalossy et al. 2016). Because of its large structural diversity, the inner bark is of high taxonomical value (Roth 1981).

Compared with wood, the mechanical contribution of bark was long considered from a passive point of view. Owing to its high second moment of area, bark is a significant contributor to stem stiffness (Niklas 1999) especially in young stems, where it occupies more than $50 \%$ of the stem area (Rosell and Olson 2014). The active role of bark was suggested by other authors (Böhlmann 1971; Fisher and Mueller 1983). Recent experiments on artificially inclined young stems in several tree species provided mechanical evidence that bark can generate large mechanical stresses (Clair et al. 2019). The underlying mechanism operates at the whole tissue level through the interaction between the radial growth of wood and tangential expansion of bark. The bark structure of some species allows redirection of the tangential strain into longitudinal tension by means of a trellis fiber network.

One of the most important aspects of this mechanism, i.e., the tangential expansion of bark, also called dilatation growth (Angyalossy et al. 2016), results from a developmental incompatibility between bark and wood. The centrifugal development of bark requires dilatation to maintain the integrity of the whole tissue when wood grows (Whitmore 1962; Evert 2006). Dilatation is often followed by a common secondary change in bark: the development of sclereids. Sclereids are isodiametric or longitudinally oriented cells that develop through the swelling of parenchyma cells and the deposition of thick secondary walls (Prislan et al. 2012). Although sclereids may also develop from early cambial derivatives (Esau 1969; Angyalossy et al. 2016), their development is almost always associated with dilatation growth (Evert 2006). Sclereids in bark are believed to play a role in mechanical support and deterrence of grazing or bark-boring organisms (Carlquist 1984; Franceschi et al. 2005).

Strong dilatation growth in rays was observed in species, producing tensile stress in bark (Clair et al. 2019). Thus, tensile stress in bark is expected to be associated with the occurrence of both dilatation of rays and trellis structure of fibers. However, the opposite should be verified, i.e., whether the occurrence of both the dilatation of rays and trellis of fibers are systematically associated with tensile stress. It is noteworthy to mention that phloem fibers with a G-layer have been observed in Eucalypts (Toghraie et al. 2006), in fiber crops such as flax (Gorshkova et al. 2010), in Gnetum gnemom (Tomlinson 2003), and several other tree species (Nakagawa et al. 2012; Crivellaro and Schweingruber 2015; Angyalossy et al. 2016). These fibers might function as they do in xylem and also contribute to generate tension within the inner bark. This raises questions as to the effects of cell development and cell wall maturation on stress generation in bark. Likewise, one should ask whether the differentiation of thick-walled cells such as sclereids also affects the mechanical state of bark.

After a thorough analysis depicting the mechanistic aspects of bark stress generation in a few botanical families (Clair et al. 2019), a broader screening of the diversity in bark mechanical stress and anatomy would enable us to assess the taxonomic extent of the mechanism of tension generation as well as the occurrence of other types of mechanisms. Although such mechanisms have been described for inclined stems, there is no evidence to suggest that mechanical stress generation in the bark of vertical trees does not occur. Moreover, it is very likely that significant stresses in their bark would be observed, because the anatomical characteristics and processes responsible for their generation, such as fiber arrangement, ray dilatation, wood growth and fiber maturation, occur in vertical trees.

Studying vertical trees also precludes the complex mechanical history of inclined stems. Indeed, the mechanical stress fields of leaning stems result from the dynamics of bending, i.e., the balance between selfweight and tension wood production, and are difficult to measure and interpret (see Clair et al. 2019, Supporting information, Notes S1).

Through the assessment of the sign and the magnitude of mechanical stress as well as the anatomical characteristics of the bark of 15 tropical species from various botanical family, this study aims $(i)$ to describe the mechanical state of bark encountered on vertical trees of 
various species, and (ii) relate mechanical stress to a diversity of anatomical structures of bark.

\section{Materials and methods}

\section{Plant material and sampling}

We selected 13 of the Amazonian tree species that were growing in plantation trials in French Guiana (initiated in 1980). Plantations were preferred to reduce the potential biases due to age differences among individuals and unknown mechanical life histories imposed by natural stand growth. To minimize a potential size-effect we selected 10 healthy trees with a diameter at breast height (DBH) ranging from 20 to $40 \mathrm{~cm}$ for each species. Six species were sampled in the plantation trial of the Paracou research station owned by the CIRAD $\left(5^{\circ} 27^{\prime} \mathrm{N}\right.$, $\left.52^{\circ} 92^{\prime} \mathrm{W}\right)$. The Paracou experimental site is located on a terra firme forest close to the coastal range, a few kilometers from the city of Sinnamary. Seven species were sampled in the plantation trial of L'Egyptienne owned by the Office National des Forêts (ONF) $\left(4^{\circ} 48^{\prime} \mathrm{N}, 52^{\circ} 20^{\prime} \mathrm{W}\right)$. The site of L'Egyptienne is located in Eastern French Guiana, close to the city of Roura. We also sampled two species in a natural secondary forest [Schefflera morototoni (Aubl.) Maguire, Steyerm. \& Frodin, and Goupia glabra Aubl.] close to the Paracou plantation site by carefully selecting vertical trees growing on flat ground and in an undisturbed area. Moreover, the fast growing habit and the short life span of these two species reduced the likelihood of a complex mechanical history.

\section{Measurement of residual strains}

Inner bark residual longitudinal strains $(\mu \mathrm{m} / \mathrm{m}$, $\mu$ strain) were measured at four positions per tree around breast height. As trees are never perfectly vertical, position 1 was chosen at the opposite side of the leaning direction. Then positions 2,3 , and 4 were selected at $90^{\circ}$ from the previous in a clockwise direction. For each measurement, the outer bark was first removed on an area of $3 \mathrm{~cm} \times 3 \mathrm{~cm}$. Then, an extensometric sensor (HBM DDL-1) (Fournier et al. 1994, 2006; Ruelle et al. 2006) consisting of one fixed pin and one moving pin was inserted in the inner bark, while carefully aligning the two pins of the sensor along the longitudinal direction of the stem. Released strains were recorded by connecting the sensor to a strain indicator (Vishay P3). After setting up the sensor in the inner bark, the strain indicator was initialized, and bark longitudinal stress release was performed by sawing two tangential grooves, one above and one below the upper and lower pin, respectively. Each groove was made at a distance of 4-7 $\mathrm{mm}$ from the corresponding pin. The bark residual longitudinal strain was defined as the value recorded after performing the second groove. The value is negative if the stress is tensile and positive if the stress is compressive. The average bark residual longitudinal strain (BRLS) per tree was computed as the arithmetic mean of the four measurements.

\section{Measurement of bark density}

After BRLS measurements were completed, one bark sample $(1 \mathrm{~cm} \times 2-3 \mathrm{~cm})$ was collected below each measurement position and immediately sealed in plastic bags for basic density measurements. Within the $24 \mathrm{~h}$ following the sampling, the green bark volume was measured using the water displacement method with a high precision scale (Sartorius). Before green volume measurement, the outer bark was carefully removed. Then, samples were oven dried for $48 \mathrm{~h}$ at $103{ }^{\circ} \mathrm{C}$ and the dry mass was recorded immediately. Inner bark basic density was computed as the ratio of dry mass to green volume.

\section{Statistical analysis}

Variation of BRLS among species was assessed using one-way ANOVA. We also partitioned the variance of BRLS according to three grouping factors: among-species, within species (i.e., among conspecific individuals), and within individual. For that purpose, we fitted a random effect model with a nested random effect structure, i.e., the among-species and within-individual being the higher and lower levels, respectively, using the lmer package (Bates et al. 2015). The relationship between BRLS and inner bark density was assessed using Pearson correlation coefficient. All statistical analyses were considered significant to the 0.05 level and conducted with $\mathrm{R}$ statistical software (R Core Team 2016).

\section{Observation and qualitative description of anatomical structure}

For each sampled species, we randomly selected a tree, and collected a bark sample $(2 \mathrm{~cm}$ in height and width, and thickness equal to bark thickness) at breast height. We prepared thin sections using a sliding microtone (GSL1; WSL) and stained the sections using Alcian Blue $8 \mathrm{GX}$ (8.3 g. $\mathrm{L}^{-1}$ in an $85 \%$ ethanol solution) counterstained with safranin (10 g. $\mathrm{L}^{-1}$ in a $50 \%$ ethanol solution). We prepared transversal sections and two to three longitudinal tangential sections at different positions between the cambium and the outer part of the inner bark.

To assess the anatomical characteristics of the bark, we recorded five qualitative criteria: (i) presence/absence of fibers; (ii) presence of G-layers if fibers are present; (iii) presence/absence of trellis organization of fibers in the longitudinal plane; (iv) location of dilatation growth (i.e., in rays or axial parenchyma); $(v)$ presence/absence of sclereids.

\section{Results}

Bark residual longitudinal strain

We observed significant differences of BRLS between species (ANOVA, $F_{[14,135]}=34.8, p<0.001$ ) (Fig. 1; Table 1), ranging from bark under strong tensile stress (Eperua falcata, -1598 $\mu$ strains) to strong compressive stress (Goupia glabra, $2582 \mu$ strains). Over the 15 species studied, the average BRLS value is significantly negative (0 lying outside the lower CI boundary) in five species, signifi- 
Fig. 1. Variation of bark residual longitudinal strain (BRLS) (A) and inner bark density (B) among the species under study. Species are ordered by increasing BRLS median values. (A) The mean ( ) and confidence intervals for each species are presented. The broken vertical line separates negative and positive values for BRLS. [Colour online.]

(A)

(B)

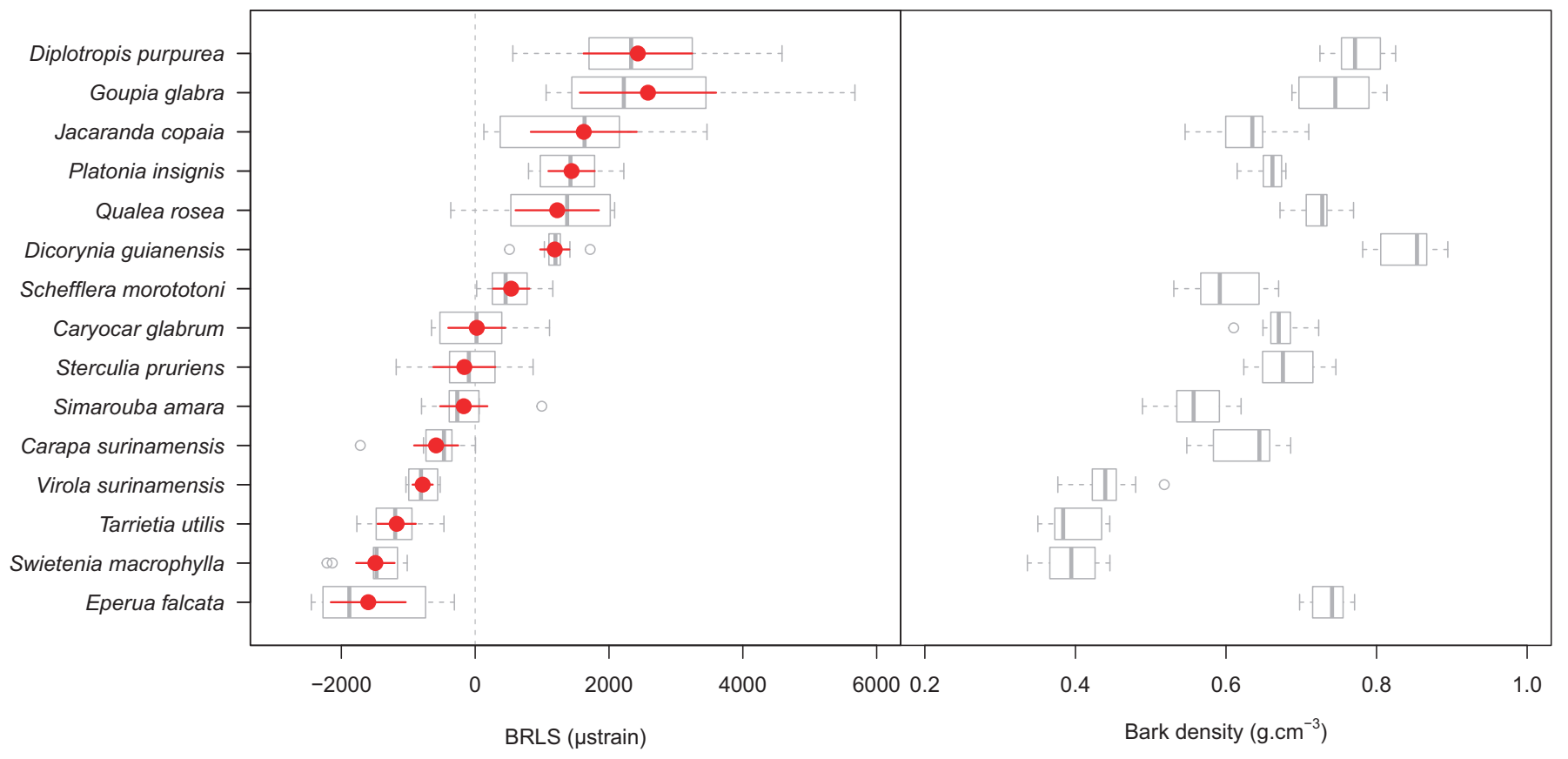

Table 1. Species under study and the average values of each measured parameter.

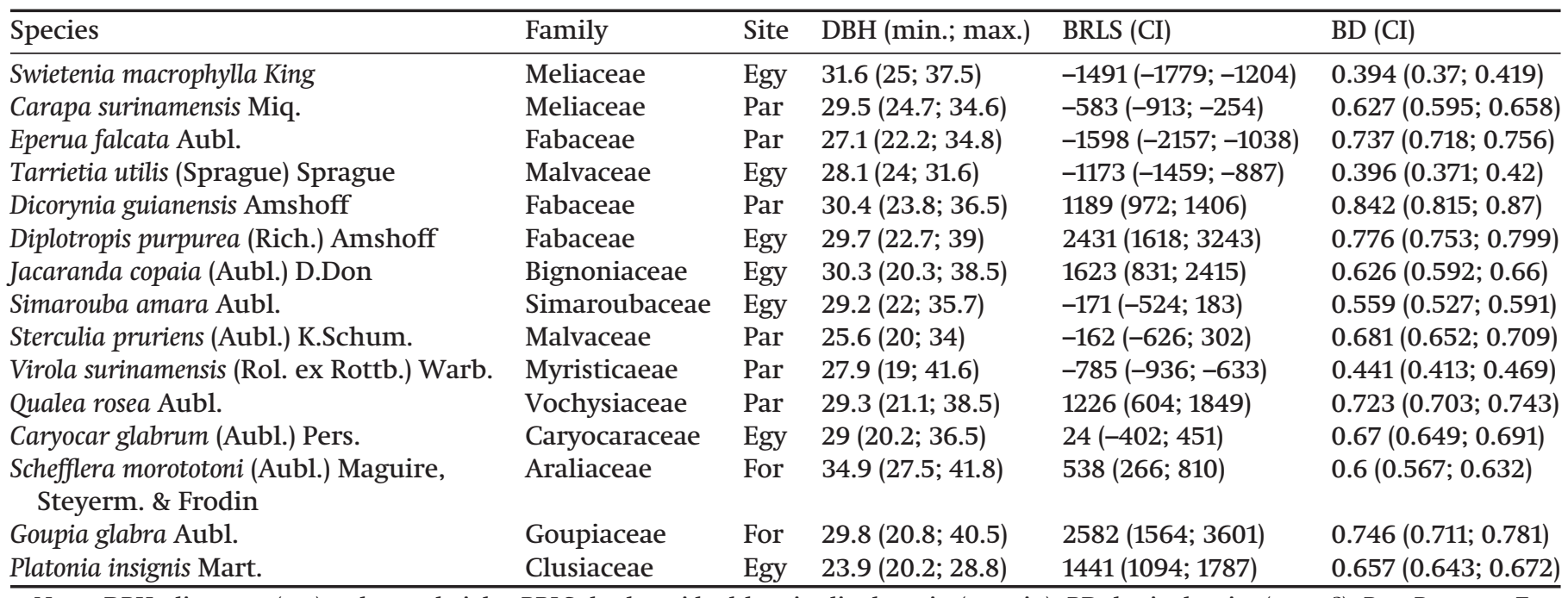

Note: DBH, diameter $(\mathrm{cm})$ at breast height; BRLS, bark residual longitudinal strain ( $\mu$ strain); BD, basic density $\left(\mathrm{g} \cdot \mathrm{cm}^{-3}\right)$; Par, Paracou; Egy, Egyptienne.

cantly positive (0 lying outside the upper CI boundary) in seven species. For three species, we could not determine the sign of the average BRLS (0 lying within the CI) (Fig. 1; Table 1). Variance partitioning reveals that the species level explains the highest proportion of variance (58.05\%) followed by the within-individual level (31.35\%) and the between-individual level (10.6\%).

\section{Basic density}

We observed significant differences in the basic density of bark among species (ANOVA, $F_{[14,135]}=128.4$, $p<0.001$ ) (Fig. 1; Table 1), ranging from low density (Swietenia macrophylla, $0.394 \mathrm{~g} \cdot \mathrm{cm}^{-3}$ ) to high density (Dicorynia guianensis, $0.842 \mathrm{~g} \cdot \mathrm{cm}^{-3}$ ). The ordering of species by increasing basic density partially agrees with the ordering by increasing BRLS (Fig. 1) consistently with a significant positive correlation between basic density and BRLS at the interspecific level ( $\rho=0.64, p=0.01)$. With the most negative BRLS (-1598 $\mu$ strains) and a relatively high average bark density value $\left(0.737 \mathrm{~g} \cdot \mathrm{cm}^{-3}\right)$, Eperua falcata might be considered as an outlier. Removing this species from 
Table 2. Anatomical characteristics of the species under study.

\begin{tabular}{|c|c|c|c|c|c|c|c|}
\hline Species & Fibers & Trellis & $\begin{array}{l}\text { Gelatinous } \\
\text { layer }\end{array}$ & Dilatation & $\begin{array}{l}\text { Dilatation } \\
\text { location }\end{array}$ & Sclerification & BRLS \\
\hline Swietenia macrophylla & Yes & Yes & Yes & Inconspicuous & $\begin{array}{l}\text { In rays and axial } \\
\text { elements }\end{array}$ & Absent & - \\
\hline Carapa surinamensis & Yes & Yes & Yes & Conspicuous & In rays & Old tissue & - \\
\hline Eperua falcata & Yes & Yes & Yes & Conspicuous & In rays & Old tissue; in rays & - \\
\hline Tarrieta utilis & Yes & Yes & Not observed & Conspicuous & In rays & Absent & - \\
\hline Diplotropis purpurea & Yes & Yes & Not observed & Conspicuous & In rays & Old tissue; in rays & + \\
\hline Jacaranda copaia & Yes & Yes & Not observed & Conspicuous & In rays & In rays & + \\
\hline Simarouba amara & Yes & Yes & Not observed & Conspicuous & In rays & $\begin{array}{l}\text { Axial elements close to the cambium; } \\
\text { in rays }\end{array}$ & $0(-)$ \\
\hline Sterculia pruriens & Yes & Yes & Not obse & Con & In rays & Old tissue; in rays & $0(-)$ \\
\hline Virola surinamensis & Yes & Yes & Not observed & Conspicuous & In rays & Axial elements; in rays & - \\
\hline Platonia insignis & No & 一 & - & Not observed & 一 & Axial elements close to the cambium & + \\
\hline
\end{tabular}

Note: For the bark residual longitudinal strain (BRLS), "0" indicates that the BRLS was not significantly different from zero; -, indicates negative BRLS; and + , indicates positive BRLS.

the dataset considerably strengthens the correlation between bark density and BRLS $(\rho=0.80, p<0.001)$.

\section{Anatomy}

Among the 15 species studied, fibers were absent in the phloem of three species, i.e., Goupia glabra, Platonia insignis, and Schefflera morototoni (Table 2). The bark of these species is characterized by the early differentiation (i.e., close to the cambium) of sclereids in axial parenchyma (Fig. 2A; Supplementary data, Figs. S6, S8, and $\mathrm{S}^{2} 0^{2}$ ). The swelling of the developing sclereids increases the distance between adjacent rays and crushes the neighboring tissues in a tangential direction (Fig. 2A). In these species, a positive BRLS is recorded. Similar anatomical features are observed in the bark of Caryocar glabrum (Supplementary data, Fig. S2 ${ }^{2}$ ), although few fibers are observed and the BRLS is not significantly different from zero (Table 1).

In the 11 species with conspicuous fibrous bark, phloem fibers are arranged in a trellis structure in the longitudinal tangential plane (Figs. 2B-2D). In these species, BRLS values may be positive, negative, or not significantly different from zero.

Fibrous bark species with negative BRLS (i.e., Carapa surinamensis, Supplementary data, Fig. S1; Eperua falcata, Supplementary data, Fig. S5; Swietenia macrophylla, Supplementary data, Fig. S13; Tarrietia utilis, Supplementary data, Fig. S14, and Virola surinamensis, Supplementary data, Fig. S15 ${ }^{2}$ ) present enlarging rays toward the periphery of the bark (Fig. 2E) that are weakly or not sclerified. Sclerified cells occur mainly in the older bark (i.e., the outer part of the phloem) or very locally in rays or axial parenchyma (Fig. 2E). Among these five species we detected fibers with a G-layer in three species (i.e., Swietenia macarophylla, Fig. 2F; Carapa surinamensis, Supplementary data, Fig. S1; and Eperua falcata, Supplementary data, Fig. $5^{2}$ ).

A group of four species have enlarging rays toward the periphery but are strikingly sclerified. Sclerification may occur close to the cambium (i.e., Dicorynia guianensis, Figs. 2G and Supplementary data, S3; Diplotropis purpurea, Supplementary data, Fig. S4; Simarouba amara, Supplementary data, Fig. $S 11^{2}$ ) or in dilated rays and in the peripheral part of the phloem (Sterculia pruriens, Supplementary data, Fig. $S 12^{2}$ ). The BRLS of these species is positive or not significantly different from 0 .

The barks of Jacaranda copaia (Fig. 2H; Supplementary data, Fig. S72) and Qualea rosea (Fig. 2I; Supplementary data, Fig. S92) also have fibers arranged in a trellis-like structure, but the dilatation phenomenon is inconspicuous in Qualea rosea, and is observable in only a few rays in Jacaranda copaia. Both species share the presence of sclerified rays near the fibers and positive BRLS.

\section{Discussion}

The measurement of BRLS on 15 tropical species highlights the occurrence of significant mechanical stress (tensile or compressive) in vertical mature trees of 12 species. Very surprisingly, significant compressive stresses (BRLS $>0$ ) are systematically observed in almost half of the sampled species (7 species). As expected, the 
Fig. 2. Diversity of bark anatomy of the studied species. (A) Transverse section of Platonia insignis showing a considerable amount of sclereids. Differentiating sclereids (dsc) observed near the cambium, lead to the curvature of rays and crushing of axial elements (broken line). The other sclereids are mature (msc). (B, C, and D) Longitudinal tangential sections close to the cambium (B), in the median region (C) and in the outer part (D) of the inner bark of Eperua falcata. With increasing distance from the cambium, phloem fibers (f) become lignified (red) and dilatation of rays occurs (white arrowhead). Development of sclereids (sc) in rays is also observed. (E) Transverse

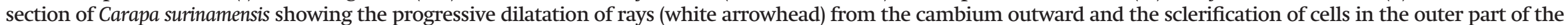
inner bark (sc). (F) Fibers with a gelatinous layer observed in transverse section in Swietenia macrophylla. (G) Transverse section of Dicorynia guianensis, with the presence of

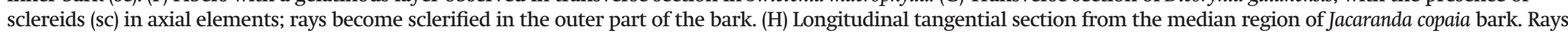
adjacent to fibers (f) are heavily sclerified (white arrowhead) and those adjacent to axial parenchyma or sieve tubes (black arrowhead) are not sclerified. (I) Transverse section of the median region of Qualea rosea bark. The rays in contact with fibers (f) are sclerified (white arrowhead). Scale bars: $\mathrm{A}=1 \mathrm{~mm}$; $\mathrm{B}, \mathrm{C}$, and $\mathrm{D}=500 \mu \mathrm{m}$; $\mathrm{E}=1 \mathrm{~mm}$; $\mathrm{F}=30 \mu \mathrm{m} ; \mathrm{G}$ and $\mathrm{H}=500 \mu \mathrm{m} ; \mathrm{I}=200 \mu \mathrm{m}$. [Colour online.]

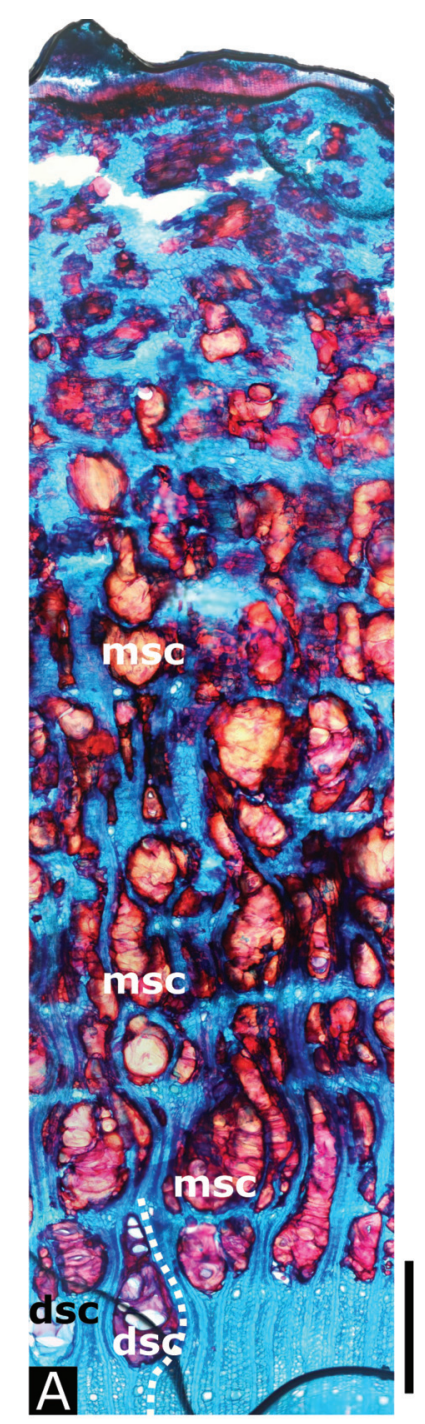

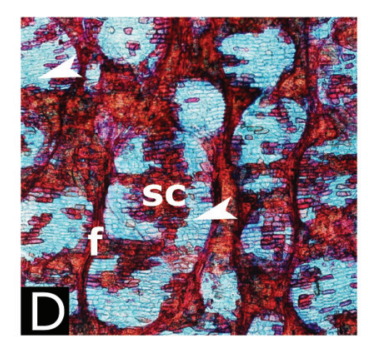

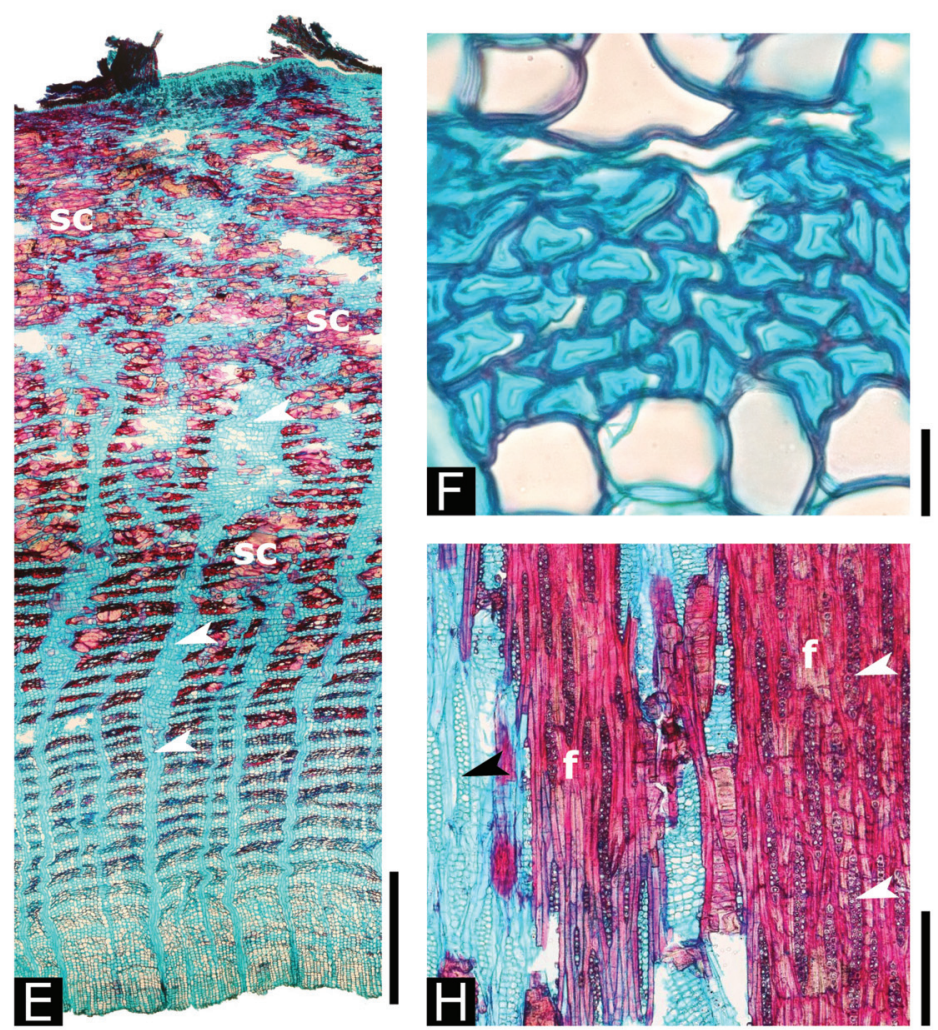
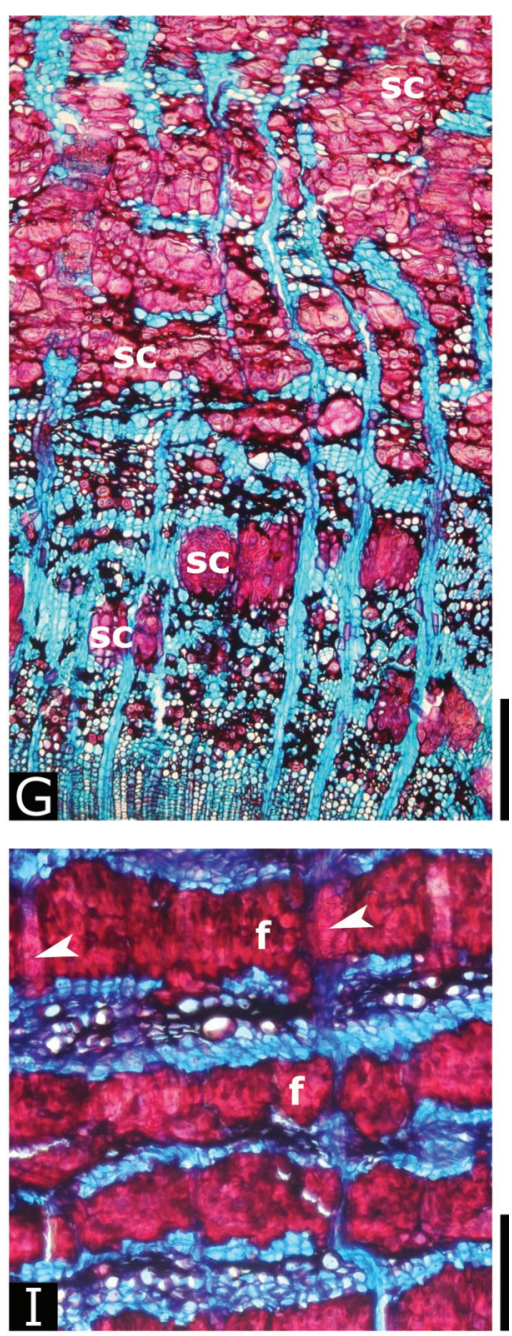
mechanism generating tension in the bark of inclined stems also occurs in vertical trees, and a significant tensile stress (BRLS $<0$ ) is measured in five species (Swietenia macrophylla, Carapa surinamensis, Eperua falcata, Tarrieta utilis, and Virola surinamensis).

Tensile stress is always associated with strong dilatation in rays (Fig. 2E) and fibers arranged in a trellis-like pattern (Figs. 2B-2D). The anatomical structure of bark in species with tensile stress is similar to that observed in Malvaceae species (Roth 1972; Kotina et al. 2017; Clair et al. 2019) or some extinct plants (Masselter et al. 2017; Poppinga and Speck 2019), and here observed in various botanical families. Among these species we observed the presence of fibers with a G-layer in three cases (Carapa surinamensis, Supplementary data, Fig. S1; Eperua falcata, Supplementary data, Fig. S5; and Swietenia macrophylla, Supplementary data, Fig. $S 13^{2}$ ), two of them being the species with the most negative BRLS (i.e., Swietenia macrophylla and Eperua falcata). This result suggests that the presence of fibers with a G-layer combined with a trellis structure produce higher tensile stress than the trellis structure made consisting of normal fibers.

Significant compressive stress (BRLS > 0) was measured in species without fibers in the bark but showing a considerable amount number of early developing sclereids (i.e., sclereids are observable from the cambium outward) (Goupia glabra, Supplementary data, Fig. S6²; Platonia insignis, Fig. 2A). The association of compressive stress, early developing sclereids, and compressed tissue surrounding the sclereids (e.g., Platonia insignis) leads us to consider the effect of sclereid differentiation on the mechanical state of bark. Mature sclereids being isodiametric cells, the swelling of the developing sclereids (Prislan et al. 2012) should produce compressive stress in all directions, including longitudinal stress, as was observed in this study. In a previous study (Clair et al. 2019), the few observations of compressive longitudinal stress in the bark of inclined mature Goupia glabra trees were interpreted as a passive effect of the stem bending during the uprighting process. Whereas sclereids are generally assumed to be implicated in mechanical support and protection (Carlquist 1984; Franceschi et al. 2005), this study supports the differentiation of sclereids as a potential origin of compressive stresses in the bark. Moreover, it is very likely that bark density is positively affected by the widespread occurrence of thick-walled cells such as sclereids (Carmo et al. 2016). The positive correlation observed between bark density and BRLS supports the involvement of sclereids in generating compressive stress. However, bark density alone should not be considered as a relevant proxy of bark mechanical state. High bark density and negative BRLS may co-occur, as exemplified with Eperua falcata in our sampling. We expect that the relatively high bark density in this species results from the presence of sclereids in both rays and older bark layers, but the compressive stress generated during their differentiation is not sufficiently high to offset the tensile stress generated by both G-layer and the fiber network.

The suspected antagonist effect of fiber networks on one hand and sclereid development on the other hand, makes the prediction of bark mechanical state difficult when both anatomical components are observed. Several species exhibit fibers arranged in a trellis structure, conspicuous ray dilatation, and sclereids. BRLS is not significantly different from 0 in Simarouba amara and Sterculia pruriens or significantly positive in Dicorynia guianensis, Diplotropis purpurea, Qualea rosea, and Jacaranda copaia. The bark of these species should generate tensile stress; however, the development of sclereids (Supplementary data, Fig. $S 1^{2}$ ) and the associated production of compressive stress likely raise the BRLS up to a positive or a neutral mechanical state.

One could ask whether the mechanical stress values measured in this study on mature trees should be similar in smaller/younger trees. It is noteworthy to mention that sclereid formation is a secondary change occurring later during ontogeny compared with fibers that are regularly produced by the cambium after the onset of secondary growth. From that point of view, we suspect that compressive stress related to the formation of sclereids might influence the mechanical state of bark in older trees. In the case of species showing both the anatomical characters of tensile and compressive stress generation (i.e., Dicorynia guianesis, Diplotropis purpurea), it therefore seems likely to observe bark under tensile stress in younger/smaller trees. The measurement of bark mechanical stress and density on a wider tree size range should provide a better assessment of the occurrence of such an ontogenetic shift in bark mechanics.

\section{Acknowledgements}

We thank the French National Forest Office (ONF) and the French Agricultural Research Centre for International Development (CIRAD) to allow the sampling in their experimental plantation sites. This work is part of the 'MechaBark' research project funded by the French National Research Agency (CEBA, ref. ANR-10-LABX-25-01 and NUMEV, ref. ANR-10-LABX-20).

\section{References}

Alméras, T., and Fournier, M. 2009. Biomechanical design and long-term stability of trees: Morphological and wood traits involved in the balance between weight increase and the gravitropic reaction. J. Theor. Biol. 256(3): 370-381. doi:10. 1016/j.jtbi.2008.10.011. PMID:19013473.

Angyalossy, V., Pace, M.R., Evert, R.F., Marcati, C.R., Oskolski, A.A., Terrazas, T., Kotina, E., Lens, F., Mazzoni-Viveiros, S.C., Angeles, G., Machado, S.R., Crivellaro, A., Rao, K.S., Junikka, L., Nikolaeva, N., and Baas, P. 2016. IAWA list of microscopic bark features. IAWA J. 37(4): 517-615. doi:10.1163/2294193220160151.

Bates, D., Maechler, M., Bolker, B., and Walker, S. 2015. Fitting linear mixed-effects models using lme4. J. Stat. Softw. 67(1): 1-48. doi:10.18637/jss.v067.i01. 
Böhlmann, D. 1971. Zugbast bei Tilia cordata Mill. Holzforschung, 25(1): 1-4. doi:10.1515/hfsg.1971.25.1.1.

Carlquist, S. 1984. Wood and stem anatomy of Lardizabalaceae, with comments on the vining habit, ecology and systematics. Bot. J. Linn. Soc. 88(4): 257-277. doi:10.1111/j.1095-8339.1984. tb01575.x.

Carmo, J.F., Miranda, I., Quilhó, T., Carvalho, A.M., Carmo, F.H.D.J., Latorraca, J.V.F., and Pereira, H. 2016. Bark characterisation of the Brazilian hardwood Goupia glabra in terms of its valorisation. BioResources, 11(2): 4794-4807. doi: 10.15376/biores.11.2.4794-4807.

Clair, B., Alteyrac, J., Gronvold, A., Espejo, J., Chanson, B., and Alméras, T. 2013. Patterns of longitudinal and tangential maturation stresses in Eucalyptus nitens plantation trees. Ann. For. Sci. 70(8): 801-811. doi:10.1007/s13595-013-0318-4.

Clair, B., Ghislain, B., Prunier, J., Lehnebach, R., Beauchêne, J., and Alméras, T. 2019. Mechanical contribution of secondary phloem to postural control in trees: the bark side of the force. New Phytol. 221(1): 209-217. doi:10.1111/nph.15375. PMID:30076782.

Crivellaro, A., and Schweingruber, F. 2015. Stem anatomical features of dicotyledons: xylem, phloem, cortex and periderm characteristics for ecological and taxonomical analyses. Kessel Publishing House, Remagen-Oberwinter, Germany.

Esau, K. 1969. The phloem. Encyclopedia of plant anatomy. Gebrüder Borntraeger, Germany.

Evert, R. 2006. Esau's plant anatomy. Meristems, cells, and tissues of the plant body: their structure, function, and development. Wiley \& Sons, USA.

Fang, C.-H., Clair, B., Gril, J., and Liu, S.-Q. 2008. Growth stresses are highly controlled by the amount of G-layer in poplar tension wood. IAWA J. 29(3): 237-246. doi:10.1163/2294193290000183.

Fisher, J.B., and Mueller, R.J. 1983. Reaction anatomy and reorientation in leaning stems of balsa (Ochroma) and papaya (Carica). Can. J. Bot. 61(3): 880-887. doi:10.1139/b83-097.

Fournier, M., Chanson, B., Thibaut, B., and Guitard, D. 1994. Mesures des déformations résiduelles de croissance à la surface des arbres, en relation avec leur morphologie. Observations sur différentes espèces. Ann. For. Sci. 51(3): 249-266. doi:10.1051/forest:19940305.

Fournier, M., Stokes, A., Coutand, C., Fourcaud, T., and Moulia, B. 2006. Tree biomechanics and growth strategies in the context of forest functional ecology. In Ecology and biomechanics: a mechanical approach to the ecology of animals and plants. Edited by A. Herrel, T. Speck, and N.P. Rowe. CRC Press, Boca Raton, Fla. pp. 1-33.

Fournier, M., Alméras, T., Clair, B., and Gril, J. 2014. Biomechanical Action and biological functions. In The biology of reaction wood. Edited by B. Gardiner, J. Barnett, P. Saranpää, and J. Gril. Springer, Berlin, Germany. pp. 139-169.

Franceschi, V.R., Krokene, P., Christiansen, E., and Krekling, T. 2005. Anatomical and chemical defenses of conifer bark against bark beetles and other pests. New Phytol. 167(2): 353376. doi:10.1111/j.1469-8137.2005.01436.x. PMID:15998390.

Gorshkova, T.A., Gurjanov, O.P., Mikshina, P.V., Ibragimova, N.N., Mokshina, N.E., Salnikov, V.V., Ageeva, M.V., Amenitskii, S.I., Chernova, T.E., and Chemikosova, S.B. 2010. Specific type of secondary cell wall formed by plant fibers. Russ. J. Plant Physiol. 57(3): 328-341. doi:10.1134/S1021443710030040.
Kotina, E.L., Oskolski, A.A., Tilney, P.M., and Wyk, B.-E.V. 2017. Bark anatomy of Adansonia digitata L. (Malvaceae). Adansonia, 39(1): 31-40. doi:10.5252/a2017n1a3.

Masselter, T., Kempe, A., Caliaro, S., Neinhuis, C., and Speck, T. 2017. Comparing structure and biomechanics of extant Carica papaya and Ochroma pyramidale stems allows re-evaluating the functional morphology of the fossil 'seed fern' Lyginopteris oldhamia. Rev. Palaeobot. Palynol. 246: 258-263. doi:10.1016/ j.revpalbo.2017.07.007.

Nakagawa, K., Yoshinaga, A., and Takabe, K. 2012. Anatomy and lignin distribution in reaction phloem fibres of several Japanese hardwoods. Ann. Bot. 110(4): 897-904. doi:10.1093/aob/ mcs144. PMID:22778147.

Niklas, K.J. 1999. The mechanical role of bark. Am. J. Bot. 86(4): 465-469. doi:10.2307/2656806. PMID:10205065.

Poppinga, S., and Speck, T. 2019. Bark, the neglected tree postural motor system. New Phytol. 221(1): 7-9. doi:10.1111/nph. 15481. PMID:30488601.

Prislan, P., Koch, G., Schmitt, U., Gričar, J., and Čufar, K. 2012. Cellular and topochemical characteristics of secondary changes in bark tissues of beech (Fagus sylvatica). Holzforschung, 66(1): 131. doi:10.1515/HF. 2011.119.

R Core Team. 2016. R: a language and environment for statistical computing. [Computer program.] Available from http:// www.R-project.org/ [accessed 10 December 2018].

Rosell, J.A., and Olson, M.E. 2014. The evolution of bark mechanics and storage across habitats in a clade of tropical trees. Am. J. Bot. 101(5): 764-777. doi:10.3732/ajb.1400109. PMID: 24812111.

Rosell, J.A., Gleason, S., Mendez-Alonzo, R., Chang, Y., and Westoby, M. 2014. Bark functional ecology: evidence for tradeoffs, functional coordination, and environment producing bark diversity. New Phytol. 201(2): 486-497. doi:10.1111/ nph.12541. PMID:24117609.

Rosell, J.A., Castorena, M., Laws, C.A., and Westoby, M. 2015. Bark ecology of twigs vs. main stems: functional traits across eighty-five species of angiosperms. Oecologia, 178(4): 10331043. doi:10.1007/s00442-015-3307-5. PMID:25842297.

Roth, I. 1972. Estructura anatomica des la corteza de alguna especies arboreas venezolanas de Bombacaceae. Acta Bot. Venez. 7(1/4): 67-72.

Roth, I. 1981. Structural patterns of tropical barks. Schweizerbart Science Publishers, Stuttgart, Germany.

Ruelle, J., Clair, B., Beauchêne, J., Prévost, M.F., and Fournier, M. 2006. Tension wood and opposite wood in 21 tropical rain forest species: 1. Occurence and efficiency of the G-layer. IAWA J. 27(3): 329-338.

Scurfield, G. 1973. Reaction Wood: Its Structure and Function: Lignification may generate the force active in restoring the trunks of leaning trees to the vertical. Science, 179(4074): 647-655. doi:10.1126/science.179.4074.647. PMID:17774092.

Toghraie, N., Parsapajouh, D., Ebrahimzadeh, H., Thibaut, B., Gril, J., and R. Yazdani Moghadam, H. 2006. Tension wood in eucalypt trees. J. Sci. (University of Tehran), 32(1): 13-22.

Tomlinson, P.B. 2003. Development of gelatinous (reaction) fibers in stems of Gnetum gnemon (Gnetales). Am. J. Bot. 90(7): 965-972. doi:10.3732/ajb.90.7.965. PMID:21659194.

Whitmore, T.C. 1962. Studies in systematic bark morphology. I. Bark morphology in Dipterocarpaceae. New Phytol. 61(2): 191-207. doi:10.1111/j.1469-8137.1962.tb06288.x. 